\title{
Effects of solar radiation on the utilization of dissolved organic matter (DOM) from two headwater streams
}

\author{
Sherri Brisco, Susan Ziegler* \\ Department of Biology, Science and Engineering Building 601, University of Arkansas, Fayetteville, Arkansas 72701, USA
}

\begin{abstract}
The effect of solar radiation on dissolved organic matter (DOM) utilization was studied in 2 contrasting streams in Arkansas, USA, from June 2002 through July 2003. Moores Creek is an agricultural stream with elevated nutrient and dissolved organic carbon (DOC) concentrations. Huey Hollow is a forest stream with low nutrient and DOC concentrations. A series of in situ experiments were conducted seasonally in both streams to assess how exposure of DOM to solar radiation impacted its utilization, measured as bacterial production following exposure and subsequent inoculation with whole stream water. Exposure of DOM to solar radiation significantly decreased its utilization during most seasons in both streams. Both streams experienced one period when exposure of DOM significantly increased bacterial production; during these periods, DOM appeared to be the least bioavailable and most photochemically reactive. In spring, ultraviolet absorption coefficients, normalized to DOC concentration, suggested a greater proportion of photoreactive DOM in Huey Hollow. Additionally the $\delta^{13} \mathrm{C}$ signature of DOM $\left(\delta^{13} \mathrm{C}_{\mathrm{DOM}}\right)$ suggested the largest terrestrial input occurred in spring when exposure of DOM significantly increased bacterial production. Both the proportion of photoreactive DOM and $\delta^{13} \mathrm{C}_{\mathrm{DOM}}$ exhibited little seasonal variation in Moores Creek; however, the relative bioavailability of DOM did vary, suggesting some change in DOM composition. In spring the relative bioavailability of DOM was lowest in Moores Creek, and DOM exposure appeared to have further reduced its bioavailability. Elevated ammonium concentrations at this time suggest photochemically enhanced humification may be an important mechanism influencing DOM cycling, and warrants study in streams impacted by agricultural land use.
\end{abstract}

KEY WORDS: Dissolved organic matter (DOM) - Ultraviolet radiation $\cdot$ Streams · Bioavailability

\section{INTRODUCTION}

Small headwater streams are sites of storage, transformation and export of organic matter and nutrients. Consequently, biogeochemical processes occurring in small streams are important to the organic matter and nutrient budgets of downstream ecosystems. Due to their large area of microbially active surfaces relative to volume of water, small streams have been identified as important locations for nutrient cycling (Peterson et al. 2001). The extent to which small streams process inorganic nitrogen appears to be dependent upon the availability of dissolved organic matter (DOM) (Bernhardt \& Likens 2002), a factor that varies substantially within and between streams (Volk et al. 1997). Proper- ties that regulate the ability of microbes to utilize DOM are therefore of central importance to our understanding of the biogeochemistry of stream ecosystems.

DOM is responsible for most of the absorption of solar ultraviolet radiation (UVR) in natural waters. Photochemical processes can alter the chemical composition of DOM, potentially changing substrate availability and consequently impacting carbon and nutrient cycling in aquatic ecosystems (Moran \& Zepp 1997, Obernosterer et al. 1999, Ziegler \& Benner 2000, Tranvik \& Bertilsson 2001, Engelhaupt et al. 2002). Photochemical transformation of DOM can result in a number of different photoproducts, including low molecular weight labile compounds (Kieber et al. 1989, Bertilsson \& Tranvik 1998, Osburn et al. 2001) dis- 
solved inorganic carbon (Miller \& Zepp 1995, Graneli et al. 1996, Anesio et al. 1999, Johannssen \& Miller 2001), and inorganic nutrients (Franko \& Heath 1982, Bushaw et al. 1996, Boavida \& Wetzel 1998, Koopmans \& Bronk 2002).

The ecological impact of these photochemical processes on DOM cycling is tightly coupled to the source and composition of DOM. Prior to any photochemical reaction, light must be absorbed by chemical species in the water. The potential photochemical reactivity of DOM, therefore, is often assessed using the UV absorptivity of a water sample. Water with high levels of terrestrially derived DOM, such as blackwater lakes and rivers, have high UV absorptivities due to elevated levels of aromatic compounds such as tannins and lignin-derived phenols (Opsahl \& Zepp 2001, Osburn et al. 2001). Consequently, exposure of DOM to solar radiation has been found to increase microbial utilization of DOM in ecosystems where organic matter is predominantly terrestrial-derived (Miller \& Moran 1997). Photochemical transformation of lignin-derived phenols, for example, into organic acids appears as one important mechanism for this increase (Kieber et al. 1989, Opsahl \& Zepp 2001). On the other hand, most labile compounds such as carbohydrates and amino acids, often derived from plant exudates, do not absorb UV light and cannot be directly altered photochemically. This does not mean that such compounds are never altered by photochemical processes. Bioavailable compounds may become involved in secondary reactions through interactions with radicals formed by initial photochemical reactions (Vaughan \& Blought 1998, Goldstone \& Voelker 2000) and possibly through humification processes (Kieber et al. 1997, Goldstone et al. 2002). Consequently, photochemical transformations can reduce the utilization of algal-derived DOM in some ecosystems (Tranvik 1998; Benner \& Biddanda 1998).

In natural water it is not only the photochemical reactivity of DOM but also the concentration of bioavailable components that may determine the effect of solar radiation on DOM utilization. Photochemical and biological processes may compete for DOM as a substrate, with the relative photoreactivity versus bioavailability of the DOM determining the overall impact on DOM utilization (Obernosterer \& Benner 2004). In ecosystems where DOM is more bioavailable, photochemical processes usually decrease or have no impact on the microbial utilization of DOM; in systems dominated by more refractory DOM, solar radiation exposure tends to increase microbial utilization of DOM (Ziegler \& Benner 2000, Tranvik \& Bertilsson 2001, Obernosterer \& Benner 2004).

Although studies have characterized the impact of solar radiation on DOM utilization in marine ecosys- tems (Miller \& Moran 1997, Obernosterer et al. 1999, Engelhaupt et al. 2002), lakes of different humic content (Geller 1986, Graneli et al. 1996, Bertilsson \& Tranvik 1998, Lindell et al. 2000, Tranvik \& Bertilsson 2001), ponds (Reitner et al. 1997, Tranvik \& Kokalj 1998), wetlands (Espeland \& Wetzel 2001) and terrestrially dominated rivers (Amon \& Benner 1996, Gao \& Zepp 1998) little is understood about these processes in small streams. Large variation in DOM source and bioavailability is likely to cause variation in the role of photochemical processes in the cycling of DOM in stream ecosystems (Volk et al. 1997). Additionally, agricultural activities and urbanization have resulted in elevated inorganic nutrient concentrations and solar radiation in many small streams.

The main focus of this study was to determine if solar radiation is responsible for altering DOM in a nutrientreplete, agricultural stream and a nutrient-depleted, forest stream. As part of a series of studies aimed at characterizing the source, composition, and bioavailability of DOM in 2 contrasting headwater streams, we have found the bioavailability of DOM in an agriculture stream to be low despite luxurious algal growth. Experiments suggest that elevated nutrient concentrations support high levels of microbial activity, resulting in a larger pool of refractory DOM relative to a more nutrient-deplete, forested stream (Ziegler \& Brisco 2004). Elevated nutrients may increase microbial degradation of terrestrial organic matter and increase both the release of humics (Kaplan \& Newbold 1993) and uptake of more labile components of DOM (Moran $\&$ Hodson 1989). The variation in source and bioavailability of DOM suggests the role of solar radiation in the cycling of DOM may be quite different between these 2 study streams. In situ experiments were conducted over the course of $1 \mathrm{yr}$ at field sites within each stream, investigating the effects of DOM exposure to solar radiation on its utilization measured as bacterial production following exposure and subsequent inoculation. Although these experiments were not designed to specifically test differences between the 2 stream types, differences in DOM sources and bioavailability in the 2 contrasting streams were expected to yield differences in the effect of solar radiation exposure on the utilization of DOM.

\section{MATERIALS AND METHODS}

Study sites. All samples were collected from 2 intermittent headwater streams located in northwest Arkansas, USA. Huey Hollow (Ozark National Forest, Crawford County) is approximately $5.6 \mathrm{~km}$ in length and drains a watershed of approximately 1130 ha dominated by hardwood deciduous forest and under- 
lain by limestone. Moores Creek (Washington County) is approximately $8.4 \mathrm{~km}$ long and drains a 2120 ha, predominately agricultural watershed underlain by shale and sandstone. Moores Creek was chosen as an impacted stream based on nutrient monitoring by the Arkansas Water Resources Center, which also provided continuous flow and discharge data for the period of this study (Vendrell et al. 1997, M. Nelson et al. unpubl. data). The substrate of both streams is primarily bedrock with areas of small boulders. Soils in both watersheds are ultisols, primarily of the order Typic Hapludults (Harper et al. 1969, Garner \& Cox 1979). The Moores Creek watershed is dominated by stony fine sandy loam, while the Huey Hollow watershed is dominated by a clayey mixed thermic profile. Moores Creek is characterized by elevated levels of dissolved organic carbon (DOC; 300 to $1200 \mathrm{mM} \mathrm{C}$ ) and inorganic nutrients (20 to $150 \mu \mathrm{M} \mathrm{N}$ and 1 to $15 \mu \mathrm{M}$ P) as compared to Huey Hollow (40 to $260 \mu \mathrm{MC}$ $\mathrm{DOC}_{i} 2$ to $30 \mu \mathrm{M} \mathrm{N}$ and 0.1 to $1.0 \mu \mathrm{M}$ P) (Ziegler \& Brisco 2004).

Sample collection. Samples were collected seasonally from the 2 study streams during baseflow conditions on clear days from June 2002 through July 2003. Discharge and flow rate was only available for the outflow of Moore Creek (M. Nelson unpubl. data, Arkansas Water Resource Center) and this data was use to verify periods of baseflow in both study streams. In 2002 extremely dry conditions in summer and fall resulted in completely dry stream beds at each site, and therefore no experiments were conducted during fall 2002. Samples were collected from an established midstream study site in each stream within an hour after sunrise. During summer 2003, additional samples were collected from 2 additional sites along Moores Creek to assess spatial variability during the most productive time of year. Site 1 is the original site located in an agricultural pasture, Site 2 is downstream $2.4 \mathrm{~km}$ from Site 1 in a wooded area, and Site 3 is downstream $4 \mathrm{~km}$ from Site 2, where Moores Creek flows into a reservoir (Lincoln Lake). Experiments were only conducted at the original midstream study site in Huey Hollow due to the low water levels during summer 2003, which limited flow to this site. Water temperature was determined using a hand held thermometer. An YSI 6920 sonde was used to continuously measure pH (YSI 6561 probe), conductivity and dissolved oxygen (YSI 6562 probe) during the course of each field experiment.

A large water sample was collected in a clean (acid washed and deionized water rinsed) 201 carboy. Samples collected from Moores Creek, where particular organic matter was quite abundant, were passed through a $35 \mathrm{~mm}$ screen to remove large particulate organic matter prior to filtration. The sample was filtered on site through a series of polycarbonate cartridge filters (Whatman 10, 1.0 and $0.2 \mathrm{~mm}$ ), which were rinsed with deionized water and stream water (>5 l each) prior to sample collection. Triplicate initial samples of the resulting filtrate (DOM sample) were collected for DOC, nitrate plus nitrite $\left(\mathrm{NO}_{3}^{-}+\mathrm{NO}_{2}^{-}\right)$, ammonium $\left(\mathrm{NH}_{4}{ }^{+}\right)$, soluble reactive phosphorus (SRP), and dissolved inorganic carbon (DIC) concentration. Samples $(10 \mathrm{ml})$ for DOC analysis were filtered through precombusted $\left(4 \mathrm{~h}, 500^{\circ} \mathrm{C}\right)$ glass fiber $(\mathrm{GF} / \mathrm{F})$ filters into precombusted glass vials $\left(4 \mathrm{~h}, 500^{\circ} \mathrm{C}\right)$ and acidified with HPLC grade $\mathrm{H}_{3} \mathrm{PO}_{4}(20 \%)$ to a $\mathrm{pH}$ of $\sim 2$. Vials were stored upright and capped with a teflon-lined cap. Samples $(3 \mathrm{ml})$ for DIC analysis were collected in clean glass vials and fixed with $\mathrm{HgCl}_{2}$ (10 ml of saturated solution). Samples collected for inorganic nutrient analyses were filtered through combusted GF/F filters into clean polyethylene tubes. Triplicate subsamples were also collected for ultraviolet (UV) absorbance and bacterial enumeration. Samples (5 ml) for bacterial enumeration were fixed with formalin ( $5 \%$ final concentration). Slides for bacterial enumeration were made within $3 \mathrm{~d}$ of sample collection to reduce potential cell lysis (Turley 1993). The water samples for DOC, inorganic nutrients, and bacterial enumeration were immediately stored on ice until transported to the laboratory. A subsample ( 2 l) of the DOM was additionally collected into a clean highdensity polyethylene bottle and stored on ice until returned to the lab where it was frozen and lyophilized for stable isotopic analysis.

The photosynthetically active radiation (PAR; 400 to $700 \mathrm{~nm}$ ), ultraviolet A (UVA; 315 to $390 \mathrm{~nm})$, and ultraviolet $\mathrm{B}(\mathrm{UVB} ; 275$ to $310 \mathrm{~nm}$ ) levels were monitored at the site throughout the incubation period with an Il 1700 radiometer (International Light Inc., Newburyport). Three different submersible, broad-band, photodiode sensors were used. Peak responses for the UVA and UVB sensors used were at 290 and $360 \mathrm{~nm}$, respectively. Light levels were measured at 5 locations on a floating incubation rack, used to incubate DOM samples for the experiments, every $2 \mathrm{~h}$ throughout each day. One measurement during each experiment was made within $1 \mathrm{~h}$ of solar noon.

Incubation experiments. Experiments conducted during each season at each site were designed to determine the effect of photochemical transformation of DOM on its bioavailability. Each large DOM sample collected as described above was dispensed into 6 light and 6 dark (wrapped in aluminum foil) quartz bottles $(300 \mathrm{ml})$. These bottles were incubated at the water surface on site for 6 to $10 \mathrm{~h}$, typically between 09:00 and 17:00 h. Following the exposure to solar radiation, a natural microbial inoculum in the form of a freshly collected, whole water sample from the study site was 
added to a subsample from each quartz bottle (light and dark) in a 1:10 dilution. Bacterial production was estimated from ${ }^{3} \mathrm{H}$-leucine incorporation during a 30 min dark incubation immediately following the inoculation. All samples were maintained within $1^{\circ} \mathrm{C}$ of ambient water temperature during the incubation for bacterial production. Samples were collected for bacterial abundance before and after filtration of the DOM sample and following the incubation of the DOM sample in all light and dark bottles to monitor abundance and potential growth of bacteria during the incubation. It has been demonstrated that short incubations may not be indicative of the bioavailable fraction of lake and wetland DOM (Obernosterer \& Benner 2004). Short incubations for determining the alteration in bioavailability of DOM were chosen for this study of stream DOM since contact between stream water DOM and the attached microbial communities are relatively short (i.e. annual average surface water residence time in Moore Creek is $<1 \mathrm{~d}_{i} \mathrm{M}$. Nelson unpubl. data).

To assess photomineralization during the incubation of the DOM sample, subsamples were collected from each quartz bottle for DOC, DIC, $\mathrm{NH}_{4}{ }^{+}, \mathrm{NO}_{3}{ }^{-}$plus $\mathrm{NO}_{2}{ }^{-}$, and SRP concentration following the on site incubation. Subsamples were also collected for UVabsorbance. All of these subsamples were collected and treated as described above and used in conjunction with the initial values to calculate changes that occurred during the in situ exposure to solar radiation.

Analyses. Bacterial abundance was determined by epifluorescence microscopy of DAPI-stained samples collected on 0.2-mm black Nuclepore filters (Porter \& Feig 1980). Over 20 fields of view were examined and over 500 cells were counted for each sample.

Bacterial production was estimated from rates of protein synthesis using ${ }^{3} \mathrm{H}$-leucine (Kirchman et al. 1985). Leucine concentration and incubation times were determined from substrate saturation curves and time course experiments for samples from each study site conducted in summer 2002. Leucine incorporation was maximal at $10 \mathrm{nM}$ and remained linear for at least $90 \mathrm{~min}$ after which incorporation dropped off slightly. All samples were incubated with a $10 \mathrm{nM}$ final concentration of ${ }^{3} \mathrm{H}$-leucine for $30 \mathrm{~min}$. One formaldehyde ( $5 \%$ final concentration)-killed control was incubated with each set of triplicate live subsamples to determine abiotic sorption of the ${ }^{3} \mathrm{H}$-leucine. Incubations were terminated by filtration through $0.2 \mathrm{~mm}$ pore size Nuclepore membrane filters and extraction with ice-cold $5 \%$ trichloroacetic acid. Following a rinse with trichloroacetic acid, filters were stored refrigerated in scintillation vials until they were analyzed for radioactivity, which occurred within $7 \mathrm{~d}$ of collection.
DOC concentrations were measured by high-temperature oxidation (Benner \& Strom 1993), and both DOC and DIC concentrations were determined using a Shimadzu TOC-5050 analyzer. Concentrations of $\mathrm{NH}_{4}{ }^{+}$ were determined by the phenol-hypochlorite method (Solorzano 1969) with a detection limit of $0.30 \mathrm{mM} \mathrm{N}$ at a confidence level $=89 \%$ and a precision of $15 \%$ (expressed as coefficient of variance). The $\mathrm{NO}_{3}{ }^{-}$plus $\mathrm{NO}_{2}^{-}$concentrations were determined by the standard cadmium reduction method modified for small samples (Gardner et al. 1976). Standards of $\mathrm{KNO}_{3}$ were analyzed before and after every set of samples. The detection limit for $\mathrm{NO}_{3}{ }^{-}$plus $\mathrm{NO}_{2}^{-}$was $0.02 \mu \mathrm{M} \mathrm{N}$ and precision was 40 and $4 \%$ at 0.02 and $1.00 \mu \mathrm{M} \mathrm{N}$, respectively. SRP concentrations were measured by the standard colorimetric method (Strickland \& Parsons 1972). The detection limit was $70 \mathrm{nM} \mathrm{P}$ and the precision was $1 \%$ at $70 \mathrm{nM}$.

Dissolved organic matter samples collected for stable isotopic analysis were lyophilized and acidified with $6 \mathrm{~N} \mathrm{HCl}$ (Pierce Chemical) in combusted glass vials. Once acidified, triplicate subsamples were dried under $\mathrm{N}_{2}$ at room temperature in silver liquid capsules (Costech). The stable carbon isotopic composition of triplicate subsamples were measured using a Carlo Erba NC 2500 elemental analyzer interfaced with a Finnigan Delta ${ }^{\text {Plus }}$ isotope ratio mass spectrometer via a Conflow II interface. Isotopic compositions were calculated by measuring samples relative to high purity, calibrated, reference gas standards expressed relative to the international standard PDB (Pee Dee Belemnite).

Absorbance at wavelengths $280 \mathrm{~nm}, 330 \mathrm{~nm}$, and $350 \mathrm{~nm}$ was measured for DOM samples using a Shimadzu spectrophotometer (UV-1201) with a $1 \mathrm{~cm}$ cell and analyzed against an identical cell of ultrapure water.

A 2 tailed $t$-test $(\alpha=0.05)$ was used to test whether bacterial production on solar light- exposed DOM samples were significantly different from bacterial production rates on the control DOM samples held in the dark. To assess seasonal and spatial changes in the impact of the exposure of DOM to solar radiation on its utilization, rates are presented as the ratio of bacterial production on light exposed DOM to bacterial production on DOM held in the dark (control).

\section{RESULTS AND DISCUSSION}

\section{Study site conditions}

Average daily water temperatures at each study site varied seasonally from 8 to $27^{\circ} \mathrm{C}$, with the only seasonal variation evidenced by a winter low. Dissolved oxygen levels were highest in winter at both sites and 
Table 1. Average water temperature, $\mathrm{pH}$, dissolved oxygen, conductivity, surface irradiance of ultraviolet A (UVA; 320 to $400 \mathrm{~nm}$ ), ultraviolet B (UVB; 280 to $320 \mathrm{~nm}$ ), and photosynthetically active radiation (PAR; 400 to $700 \mathrm{~nm}$ ) measured approximately at solar noon at Moores Creek and Huey Hollow from June 2002 through July 2003

\begin{tabular}{|c|c|c|c|c|c|c|c|c|}
\hline Site & Season & $\begin{array}{c}\text { Temperature } \\
\left({ }^{\circ} \mathrm{C}\right)\end{array}$ & $\mathrm{pH}$ & $\begin{array}{c}\text { Dissolved } \\
\text { oxygen } \\
\left(\mathrm{mg} \mathrm{l}^{-1}\right)\end{array}$ & $\begin{array}{c}\text { Conductivity } \\
(\mu S)\end{array}$ & $\begin{array}{c}\text { UVA } \\
\left(\mu \mathrm{W} \mathrm{cm}^{-2}\right)\end{array}$ & $\begin{array}{c}\text { UVB } \\
\left(\mathrm{nW} \mathrm{cm}{ }^{-2}\right)\end{array}$ & $\begin{array}{c}\text { PAR } \\
\left(\mathrm{mW} \mathrm{cm}^{-2}\right)\end{array}$ \\
\hline \multirow[t]{6}{*}{ Moores Creek } & Summer & 23 & 7.54 & 7.7 & 204 & 14.5 & 7.6 & 0.41 \\
\hline & Winter & 8 & 7.99 & 20.1 & 155 & 8.9 & 1.3 & 0.30 \\
\hline & Spring & 22 & 7.27 & 10.2 & 167 & 22.0 & 8.0 & 0.45 \\
\hline & Summer Site 1 & 24 & 7.32 & 7.6 & 121 & 17.9 & 1.3 & 0.67 \\
\hline & Site 2 & 22 & 7.92 & 9.8 & 173 & 9.7 & 5.2 & 0.24 \\
\hline & Site 3 & 23 & 7.33 & 5.6 & 110 & 23.2 & 5.4 & 0.56 \\
\hline \multirow[t]{4}{*}{ Huey Hollow } & Summer & 21 & 7.23 & 5.4 & 58 & 17.6 & 8.5 & 0.56 \\
\hline & Winter & 10 & 6.17 & 12.5 & 27 & 11.0 & 3.4 & 0.35 \\
\hline & Spring & 21 & 7.90 & 4.9 & 35 & 4.6 & 1.7 & 0.06 \\
\hline & Summer & 23 & 7.21 & 6.7 & 130 & 20.0 & 7.9 & 0.55 \\
\hline
\end{tabular}

ranged from 5.6 to $20.1 \mathrm{mg} \mathrm{l}^{-1}$ in Moores Creek and 4.9 to $12.5 \mathrm{mg} \mathrm{l}^{-1}$ in Huey Hollow. Conductivity was highest in Moores Creek during summer 2002 and ranged from 110 to $204 \mathrm{mS}$. In Huey Hollow, the highest conductivity occurred in summer 2003 and ranged from 27 to $130 \mathrm{mS}$ (Table 1).

Both UV and PAR light levels at the 2 study sites varied seasonally and were somewhat lower than levels measured at a similar latitude under an open sky which was likely due to canopy cover and topography (Biddanda \& Cotner 2003). The Moores Creek on-site light measurements were roughly 70 to $90 \%$ that of open sky measurements made at solar noon using the same light meter and sensors while Huey Hollow measurements ranged from 15 to $90 \%$ that of open sky measurements. The lowest light levels at Moores Creek occurred during the winter and the highest levels occurred during the summer, with summer 2003 having higher levels than summer 2002. In contrast, Huey Hollow had the lowest light levels in the spring and the highest levels occurred during the summer months, corresponding to a greater canopy cover in spring versus winter (Table 1). Levels of UVB and UVA, measured within $1 \mathrm{~h}$ of solar noon, ranged from 1.3 to $8.0 \mathrm{nW} \mathrm{cm}^{-2}$ at Moores Creek and 1.7 to $8.5 \mathrm{nW}$ $\mathrm{cm}^{-2}$ at Huey Hollow and from 8.9 to $23.2 \mathrm{~mW} \mathrm{~cm}^{-2}$ at Moores Creek and from 4.6 to $20.0 \mathrm{~mW} \mathrm{~cm}^{-2}$ at Huey Hollow, respectively. PAR levels, measured within $1 \mathrm{~h}$ after solar noon, at Moores Creek ranged from 0.3 to $0.7 \mathrm{~mW} \mathrm{~cm}^{-2}$ and at Huey Hollow from 0.06 to $0.56 \mathrm{~mW} \mathrm{~cm}^{-2}$.

Inorganic nutrient concentrations were highest during spring at both the
Moores Creek and Huey Hollow sites with overall values highest in Moores Creek. Ammonium levels varied from 0.9 to $3.7 \mu \mathrm{M} \mathrm{N}$, with a spike of $20.6 \mu \mathrm{M} \mathrm{N}$ in spring, at Moores Creek and from 1.0 to $5.2 \mu \mathrm{M} N$ at Huey Hollow. SRP levels ranged from 0.5 to $2.5 \mu \mathrm{M} P$ and from 0.2 to $0.4 \mu \mathrm{M} P$ at Moores Creek and Huey Hollow, respectively. Nitrate plus nitrite concentrations ranged from 0.5 to $33.6 \mu \mathrm{M} \mathrm{N}$ at Moores Creek and from 0.8 to $6.9 \mu \mathrm{M} \mathrm{N}$ at Huey Hollow (Table 2). The lowest DOC concentrations occurred during the winter at both sites and ranged from 328 to $841 \mu \mathrm{M} \mathrm{C}$ at Moores Creek and from 59 to $151 \mu \mathrm{M}$ C at Huey Hollow. The highest levels of DOC at both sites occurred when stream water had pooled during dry periods when surface water flow ceased and only limited underground flow persisted. At these times samples were collected from the largest pool within the study site reach. Stream water pooled at the Moores Creek site in summer 2002 and during the summer 2003 at the Huey Hollow site (Table 3).

Table 2. Ammonium $\left(\mathrm{NH}_{4}{ }^{+}\right)$, soluble reactive phosphorus (SRP), and nitrate plus nitrite $\left(\mathrm{NO}_{3}^{-}\right)$concentration (mean $\pm \mathrm{SD}, \mathrm{n}=3$ ) for samples collected prior to incubation from Moores Creek and Huey Hollow (June 2002 to July 2003)

\begin{tabular}{|llrrr|}
\hline Site & Season & $\mathrm{NH}_{4}{ }^{+}(\mu \mathrm{MN})$ & $\mathrm{SRP}(\mu \mathrm{MP})$ & $\mathrm{NO}_{3}{ }^{-}(\mu \mathrm{M} \mathrm{N})$ \\
\hline Moores Creek & Summer & $1.3 \pm 0.03$ & $0.47 \pm 0.00$ & $14.9 \pm 1.00$ \\
& Winter & $2.0 \pm 0.06$ & $2.80 \pm 0.05$ & $33.6 \pm 1.50$ \\
& Spring & $20.6 \pm 0.67$ & $1.37 \pm 0.21$ & $1.6 \pm 0.69$ \\
& Summer Site 1 & $3.7 \pm 0.50$ & $0.92 \pm 0.08$ & $0.5 \pm 0.09$ \\
& Site 2 & $0.9 \pm 0.34$ & $2.48 \pm 0.20$ & $3.6 \pm 0.21$ \\
Huey Hollow & Site 3 & $2.2 \pm 0.13$ & $0.28 \pm 0.09$ & $1.0 \pm 0.05$ \\
& Summer & $1.0 \pm 0.16$ & $0.23 \pm 0.08$ & $6.8 \pm 0.81$ \\
& Winter & $2.0 \pm 0.09$ & $0.21 \pm 0.00$ & $2.4 \pm 0.23$ \\
& Spring & $5.2 \pm 0.31$ & $0.38 \pm 0.00$ & $0.8 \pm 0.24$ \\
& Summer & $1.7 \pm 0.05$ & $0.26 \pm 0.00$ & $2.1 \pm 0.02$ \\
\hline
\end{tabular}


Table 3. Initial DOC concentration, stable carbon isotopic composition $\left(\delta^{13} \mathrm{C}\right)$ of DOM (means $\left.\pm 1 \mathrm{SD}, \mathrm{n}=3\right)$, and the absorbance coefficient (a) for $280 \mathrm{~nm}, 330 \mathrm{~nm}$, and $350 \mathrm{~nm}$ for initial DOM samples collected for incubation experiments conducted at Moores Creek and Huey Hollow from June 2002 through July 2003

\begin{tabular}{|c|c|c|c|c|c|c|}
\hline Site & Season & $\mathrm{DOC}(\mu \mathrm{M} \mathrm{C})$ & $\delta^{13} \mathrm{C}$ & $a_{280}\left(\mathrm{~m}^{-1}\right)$ & $a_{330}\left(\mathrm{~m}^{-1}\right)$ & $a_{350}\left(\mathrm{~m}^{-1}\right)$ \\
\hline \multirow[t]{6}{*}{ Moores Creek } & Summer & $841 \pm 0.8$ & $-25.09 \pm 0.26$ & 424 & 170 & 120 \\
\hline & Winter & $328 \pm 6.8$ & $-25.51 \pm 0.24$ & 226 & 110 & 81 \\
\hline & Spring & $649 \pm 0.8$ & $-25.67 \pm 0.39$ & 338 & 168 & 127 \\
\hline & Summer Site 1 & $557 \pm 7.4$ & $-26.33 \pm 0.65$ & 336 & 156 & 115 \\
\hline & Site 2 & $578 \pm 5.2$ & $-25.61 \pm 0.17$ & 340 & 167 & 124 \\
\hline & Site 3 & $582 \pm 1.9$ & $-26.16 \pm 0.32$ & 333 & 142 & 108 \\
\hline \multirow[t]{4}{*}{ Huey Hollow } & Summer & $70 \pm 2.8$ & $-33.30 \pm 0.92$ & 25 & 7 & 2 \\
\hline & Winter & $59 \pm 4.9$ & $-28.20 \pm 0.16$ & 116 & 70 & 58 \\
\hline & Spring & $151 \pm 4.3$ & $-25.78 \pm 0.24$ & 170 & 104 & 95 \\
\hline & Summer & $120 \pm 5.6$ & $-28.67 \pm 0.15$ & 35 & 14 & 14 \\
\hline
\end{tabular}

\section{Source and photoreactivity of stream DOM}

Seasonal variation in the UV absorption coefficients of stream water suggests the photoreactivity of DOM changed seasonally in both sites. The UV absorption coefficients of DOM samples were highest in those samples from Moores Creek (Table 3). These absorption coefficients for wavelengths $280 \mathrm{~nm}, 330 \mathrm{~nm}$, and $350 \mathrm{~nm}$ ranged from 226 to $425 \mathrm{~m}^{-1}, 110$ to $170 \mathrm{~m}^{-1}$, and 81 to $127 \mathrm{~m}^{-1}$, respectively. The absorption coefficients for DOM samples from the Huey Hollow site were generally lower, ranging from 25 to $170 \mathrm{~m}^{-1}, 7$ to $104 \mathrm{~m}^{-1}$, and 2 to $95 \mathrm{~m}^{-1}$ for wavelengths 280,330 , and $350 \mathrm{~nm}$, respectively. Although absorption coefficients were considerably lower in Huey Hollow, the absorption coefficients normalized to DOC concentration suggest that the relative proportion of photoreactive DOM was often greater in Huey Hollow. The proportion of photoreactive DOM also varied substantially in Huey Hollow but varied little in Moores Creek, suggesting greater change in DOM composition occurred in Huey Hollow during the study period.

The $\delta^{13} \mathrm{C}$ values of DOM collected from Huey Hollow range from -33.3 to $-25.9 \%$ o during the study and indicate seasonal variation in the importance of algal versus terrestrial sources of DOM (Table 3). In Huey Hollow carbon isotopic composition of leaf debris varies between -28.9 and $-27.3 \%$, stream side soil organic matter between -26.3 and $-25.7 \%$, and algae ranges from -39.9 to $-31.6 \%$ (Ziegler \& Brisco 2004). Consistently deplete $\delta^{13} \mathrm{C}$ signatures for algae have been documented previously in Huey Hollow (Ziegler \& Brisco 2004) and other streams in the region (D. Magoulick \& G. Piercey unpubl. data) and is likely the result of lower rates of production and more ${ }^{13} \mathrm{C}$ deplete sources of DIC. This distinct algal isotopic signature makes it possible to distinguish algal versus terrestrial inputs in Huey Hollow. The highest absorption coefficients for DOM collected at Huey Hollow conincided with more enriched $\delta^{13} \mathrm{C}_{\mathrm{DOM}}$, suggesting terrestrial sources were more important at those times (Table 3).

The lack of variation in both DOC-normalized UV absorptivity and isotopic composition of DOM suggests seasonal variation in the composition of DOM did not occur in Moores Creek to the extent it did in Huey Hollow. The $\delta^{13} \mathrm{C}$ values of DOM collected from Moores Creek ranged from -26.3 to -25.1 and suggests soil organic matter (soil $\delta^{13} \mathrm{C}$ ranges from -26.9 to $-25.0 \%$ in Moores Creek watershed; Ziegler \& Brisco 2004) was an important source contributing to the potential photoreactivity of DOM. Algal $\delta^{13} \mathrm{C}$ values in Moore Creek occasionally overlap soil $\delta^{13} \mathrm{C}$ signatures. A more in depth study of the isotopic composition of potential sources of DOM in Moore Creek, however, suggests soil organic matter is likely the dominant source through the year (Ziegler \& Brisco 2004). The absolute concentration of DOC and its associated photoreactive components in Moores Creek was greatest in summer 2002, suggesting the concentration of photochemically reactive DOM was greatest at that time. Elevated DOC concentrations have been linked to elevated levels of photoreactive DOM in other streams and rivers where soil organic matter was an important source of DOM (Clair \& Sayer 1997).

\section{Photochemical transformation of stream DOM}

A reduction in absorption coefficients for ultraviolet wavelengths 280, 320 and $350 \mathrm{~nm}$ occurred in DOM samples exposed to light relative to both the initial and dark control DOM samples from Moores Creek only (Fig. 1). No decrease in absorption coefficients was detected in dark control samples following incubation except in winter, which suggests some photochemical change likely caused the decrease in the absorptivity of the light exposed DOM samples (Fig. 1). In Moores Creek during summer 2003, however, there was an 
increase in absorption coefficients in dark controls relative to the initial DOM sample possibly attributed to bacterial growth in these bottles. Similar growth occurred in the light exposed samples but the absorption coefficients decreased, suggesting, again, that photobleaching of DOM occurred. During the study, 50 to $90 \%$ of the bacteria were removed from the sample prior to incubation at Moores Creek as opposed to a range of 70 to $95 \%$ at Huey Hollow. The lower filtration efficiency of Moores Creek samples is attributed to the presence of a larger number of small $(<0.2 \mathrm{~mm})$ bacterial cells. Changes in bacterial abundance occurred during the incubation of some bottles. The maximum carbon utilized during any of these incubations of Moore Creek DOM, estimated from a bacterial carbon content of $100 \mathrm{fg} \mathrm{C}^{\mathrm{C}}$ cell $^{-1}$ and a range of 10 to $50 \%$ growth efficiency (Saunders et al. 1980, Bratbak 1985) was between 0.02 and $0.09 \mu \mathrm{M}$ C. In those instances when bacterial growth occurred no significant differences ( $t$-test; $\alpha=0.05$ ) in growth within dark versus light bottles were detected. This suggests microbial utilization of DOM during the incubation was not likely a major factor contributing to differences detected in measures on exposed versus unexposed DOM samples following the incubation.

We were unable to detect photomineralization of DOM since no significant differences in DOC, DIC, SRP, $\mathrm{NO}_{3}^{-}$plus $\mathrm{NO}_{2}{ }^{-}$, and $\mathrm{NH}_{4}{ }^{+}$concentrations were detected between initial samples and either light or dark final samples from either study stream. This lack of measurable difference indicates that rates of photomineralization were below the detection limits of the methods used $\left(0.33 \mu \mathrm{MC} \mathrm{h}^{-1}, 7 \mathrm{nM} \mathrm{N} \mathrm{h}^{-1}\right.$, and $0.5 \mathrm{nM} \mathrm{P}$ $\mathrm{h}^{-1}$, respectively, for $\mathrm{C}, \mathrm{N}$, and $\mathrm{P}$ ) given the incubation periods for the experiments conducted. Though our approach of assessing photomineralization was not the most sensitive available (Miller \& Zepp 1995), we sought to limit sample manipulation to best determine the significance of photoprocesses to microbial utilization of DOM. The detection limits and precision for the method used to measure DOC concentration suggest the upper limit for net photomineralization rates, normalized to absorbance at $350 \mathrm{~nm}$, ranged from 0.003 to $0.004 \mu \mathrm{M} \mathrm{C} \mathrm{m} \mathrm{h}{ }^{-1}$ in Moores Creek and 0.004 to $0.175 \mu \mathrm{M} \mathrm{C} \mathrm{m} \mathrm{h}^{-1}$ in Huey Hollow. These rates are substantially lower than those that have been reported for other freshwater environments ranging from eutrophic clearwater to oligotrophic blackwater ecosystems $(0.2$ to $0.3 \mu \mathrm{M} \mathrm{C} \mathrm{m} \mathrm{h}^{-1}$ normalized to absorbance at $350 \mathrm{~nm}$; Miller \& Zepp 1995). This suggests that photomineralization was not likely a major fate for DOM in these study streams. Low rates of photomineralization of the stream DOM in this study could be attributed to the low levels of solar radiation characteristic of the in situ incubation conditions (Table 1). These light fluxes are
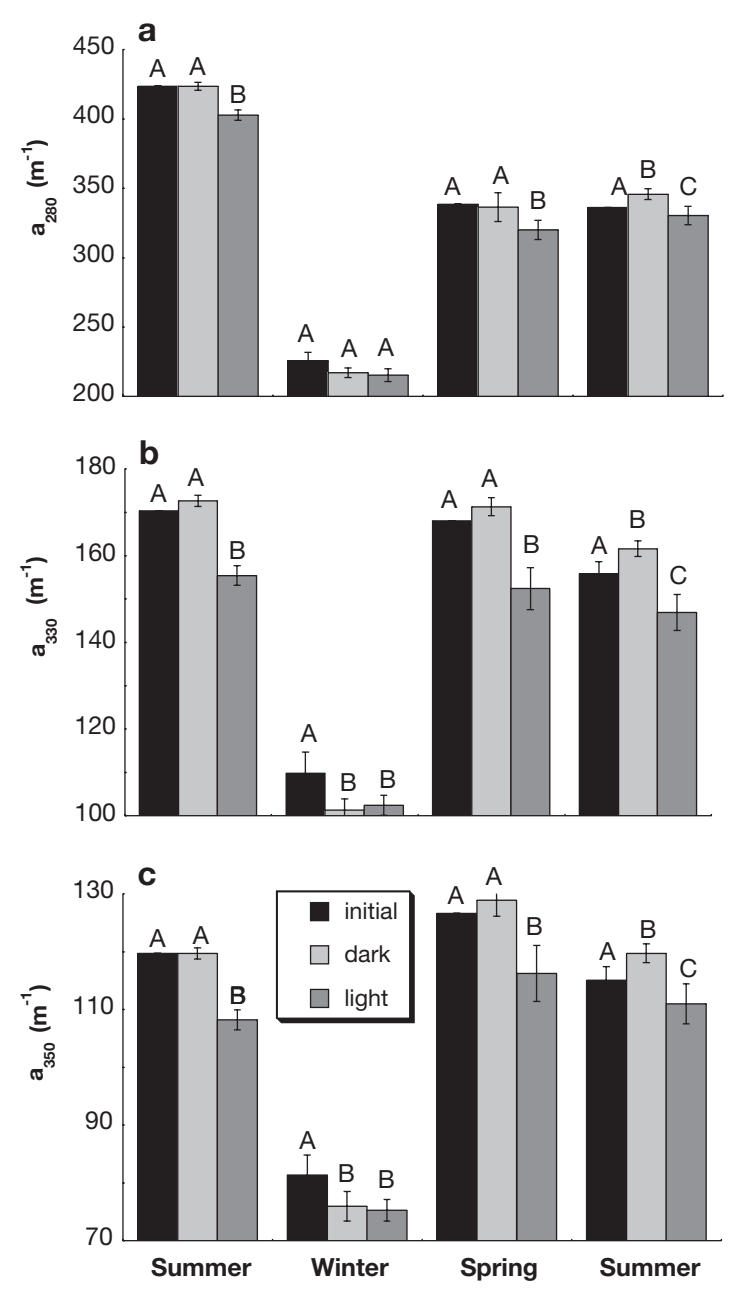

Fig. 1. Absorbance coefficients for (a) $280 \mathrm{~nm}\left(a_{280}\right)$, (b) $330 \mathrm{~nm}$ $\left(a_{330}\right)$, and (c) $350 \mathrm{~nm}\left(a_{350}\right)$ (for initial and final light and dark treatment DOM samples) from incubations experiments conducted at site 1 in Moores Creek. Values are reported as the mean \pm 1 SD where $n=3$. Means within an individual season labeled with different letters are significantly different $(\mathrm{p}<0.05)$

orders of magnitude lower than those used in experiments where photomineralization has been measured using solar simulated light sources (Moran et al. 2000).

\section{Impact of solar radiation exposure on stream DOM utilization}

Temporal variation in the bioavailability of DOM within a single stream can be large (Sondergaard \& Middleboe 1995, Volk et al. 1997) and the greater variability and complexity of freshwater DOM may lead to greater variation in photochemical processing (Clair \& Sayer 1997). The results of the DOM incubation experiments presented are as variable within each study site 

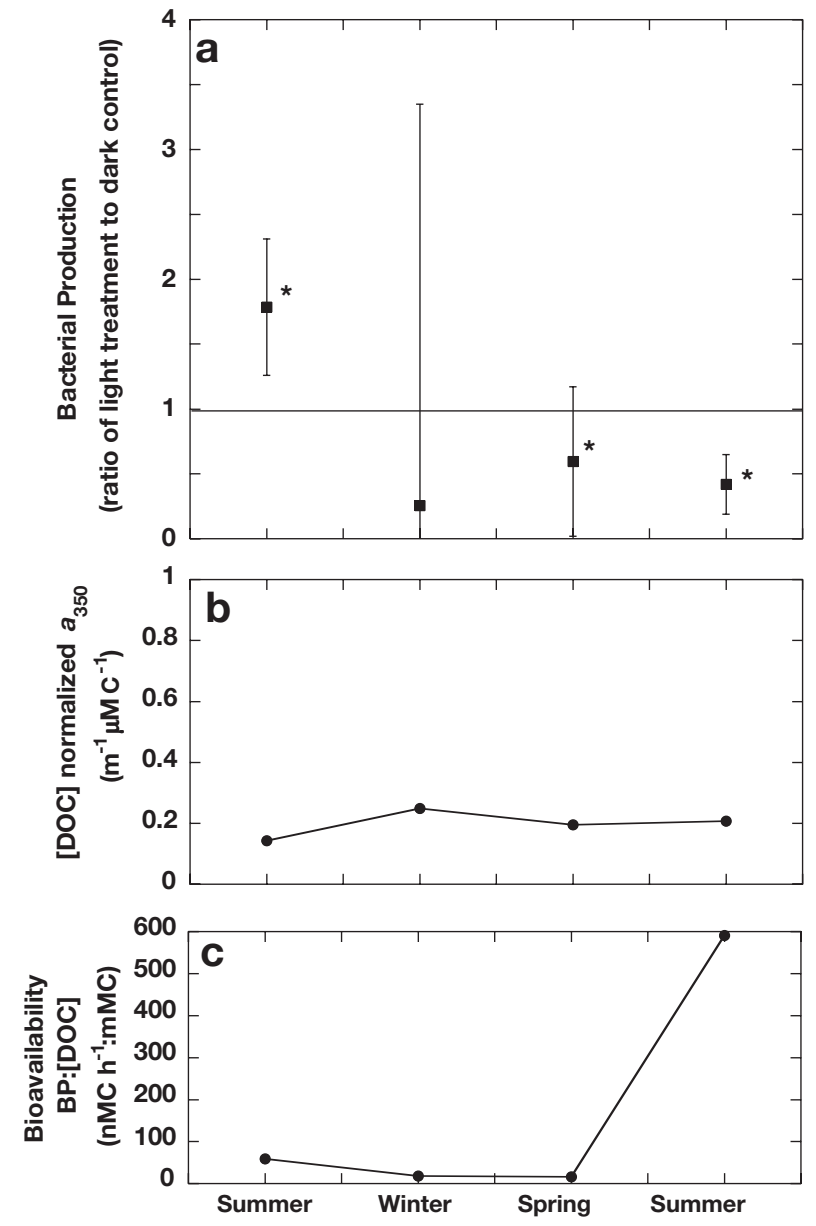

Fig. 2. (a) Ratio of bacterial production (BP) on light exposed DOM to bacterial production on dark control DOM (mean \pm the cumulative $\mathrm{SD}, \mathrm{n}=6$ ) from incubation experiments from 2002 through 2003 in Moores Creek. Data where bacterial production on light exposed DOM was significantly different $(p<0.05)$ from bacterial production on DOM held in the dark for the same period are marked with *. Horizontal line signifies no difference between light and dark results. (b) Absorbance coefficients at $350 \mathrm{~nm}\left(a_{350}\right)$ normalized to dissolved organic carbon concentration [DOC] for Moores Creek DOM samples collected from 2002 through 2003. (c) Relative bioavailability of DOM of samples collected from Moores Creek between 2002 and 2003. Relative bioavailability is calculated as the ratio of dark (control) bacterial production $\left(\mathrm{BP} ; \mathrm{nM} \mathrm{C} \mathrm{h}^{-1}\right)$ to dissolved organic carbon concentration (DOC; mM C)

as between each site during any given season (Figs. 2a $\& 3 a)$. Seasonal differences in DOM chemical composition, evidenced by variation in photoreactivity and bioavailability of DOM, likely influenced the net effect of exposure of DOM to solar radiation on subsequent bacterial production. The variation in DOM photoreactivity and bioavailability, however, was likely driven by different mechanisms in the 2 contrasting streams studied.
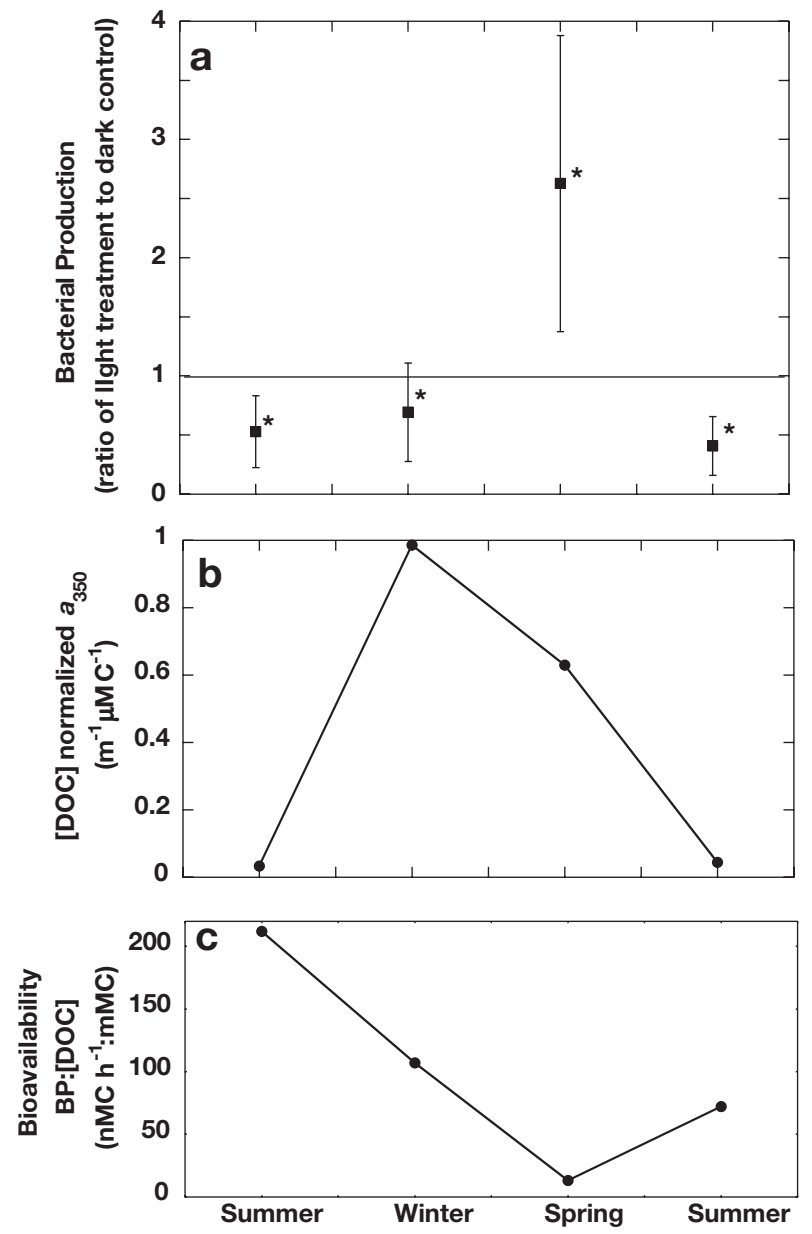

Fig. 3. (a) Ratio of bacterial production (BP) on light exposed DOM to bacterial production on dark control DOM (mean \pm the cumulative $\mathrm{SD}, \mathrm{n}=6$ ) from incubation experiments from 2002 through 2003 in Huey Hollow. Data where bacterial production on light exposed DOM was significantly different $(p<0.05)$ from bacterial production on DOM held in the dark for the same period are marked with *. (b) Absorbance coefficients at $350 \mathrm{~nm}\left(a_{350}\right)$ normalized to dissolved organic carbon concentration [DOC] for Huey Hollow DOM samples collected from 2002 through 2003. (c) Relative bioavailability of DOM of samples collected from Huey Hollow between 2002 and 2003. Relative bioavailability is calculated as the ratio of dark (control) bacterial production $\left(\mathrm{BP} ; \mathrm{nM} \mathrm{C} \mathrm{h}^{-1}\right)$ to dissolved organic carbon concentration (DOC; mM C)

\section{Positive effects of DOM exposure to solar radiation on bacterial production}

During the one period when exposure of DOM to solar radiation increased bacterial production in both streams, DOM appeared to possess the most photoreactive and least bioavailable qualities (Figs. $2 \& 3$ ). The isotopic composition of DOM and higher UV absorption coefficients suggests more terrigenous and 
photoreactive DOM was likely present in spring when exposure of DOM to solar radiation increased bacterial production in Huey Hollow (Fig. 3). The increase in DOM utilization following exposure to solar radiation in spring was, therefore, likely due to photochemical transformation of less bioavailable, terrestrially derived DOM in Huey Hollow.

In nutrient-rich streams, as with other nutrient-rich ecosystems, microbial activity can often be limited by bioavailable DOM (Amon \& Benner 1996, Tranvik \& Hofle 1987, Ziegler \& Brisco 2004). Elevated nutrients may increase microbial degradation of terrestrial organic matter and increase both the release of humics (Kaplan \& Newbold 1993) and uptake of more labile components of DOM (Moran \& Hodson 1989). Additionally, macromolecular complexes generated during microbial degradation of organic matter can reduce the bioavailability of DOM (Lara et al. 1997, Nagata et al. 1998, Osburn et al. 2001). In Moores Creek elevated inorganic nutrient concentrations may have supported microbial processing of DOM altering its chemical composition and its bioavailability. The relative bioavailability of DOM was quite different between summer 2002 and 2003 suggesting some variation in DOM composition (Figs. 2c \& 4c). Surface water flow ceased and water persisted in distinct pools with some limited underground flow typical of headwater streams in the Ozark highland region during dry summers such as in 2002. Dissolved organic matter, from the pool formed at the main study site in Moore Creek in summer 2002, appeared to be more photoreactive and less bioavailable relative to DOM collected when water was flowing in summer 2003 (Figs. 2b,c \& 4b,c). Consequently, solar UV exposure of DOM had a positive effect on bacterial production in summer 2002. Previous studies in Moores Creek have indicated higher stream water respiration rates, indicative of elevated microbial activity, when water is pooled during dry periods in summer (Ziegler \& Brisco 2004). The elevated bacterial numbers in the stream water in summer 2002 suggest a greater level of microbial activity when the water pooled, possibly resulting in production of more photoreactive and less bioavailable substrates (Osburn et al. 2001).

\section{Negative effects of solar radiation on the utilization of stream DOM}

The negative effect of solar radiation on bacterial utilization of DOM has been described less frequently than positive effects of solar radiation in different aquatic ecosystems (Benner \& Biddanda 1998, Obernosterer et al. 1999, Tranvik \& Bertilsson 2001) but was common during this study in both streams (Figs. 2a, 3a
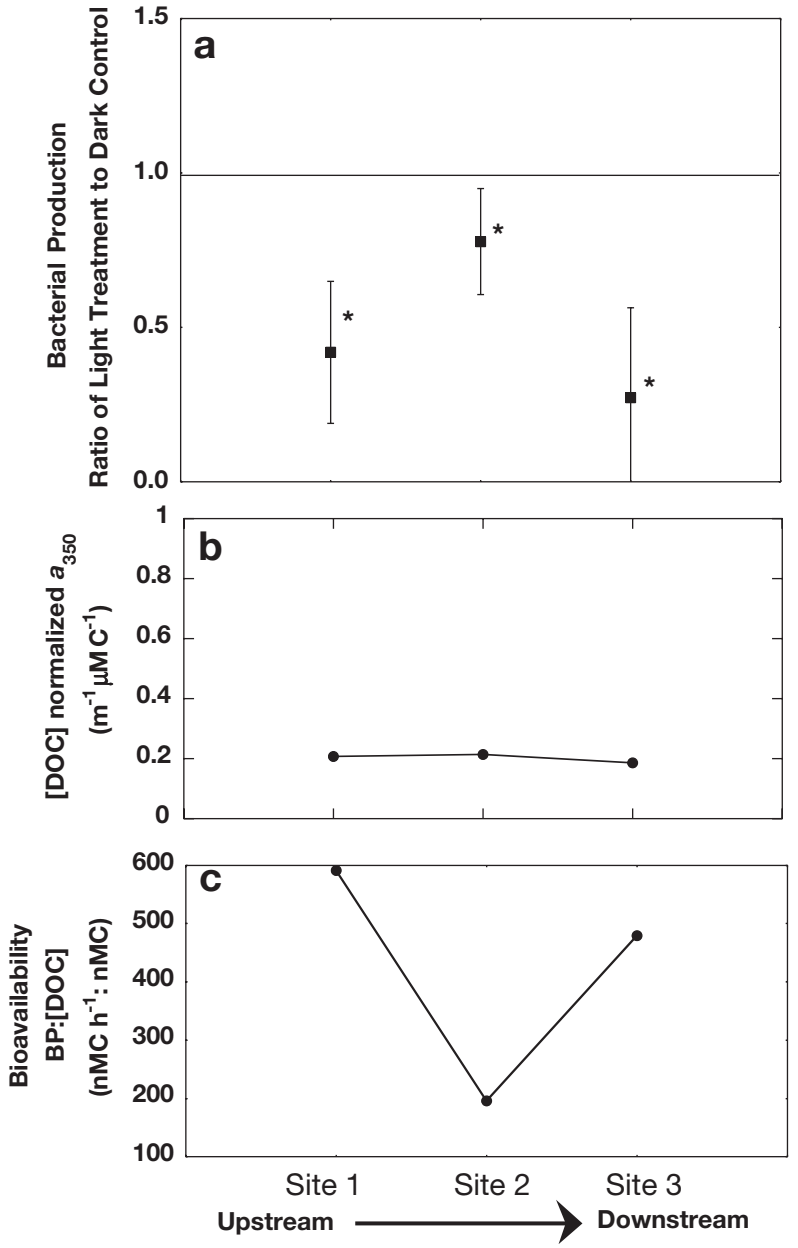

Fig. 4. (a) Ratio of bacterial production (BP) on light exposed DOM to bacterial production on dark control DOM from incubation experiments conducted in July 2003 at 3 sites in Moores Creek (mean $\pm \mathrm{SD}, \mathrm{n}=6$ ). Data where bacterial production on light exposed DOM was significantly different $(\mathrm{p}<$ 0.05 ) from bacterial production on DOM held in the dark for the same period are marked with *. (b) Absorbance coefficients at $350 \mathrm{~nm}\left(a_{350}\right)$ normalized to dissolved organic carbon concentration [DOC] for DOM samples from incubation experiments conducted in July 2003 at 3 sites in Moores Creek 2003. (c) Relative bioavailability of DOM of samples collected in July 2003 at 3 sites in Moores Creek. Relative bioavailability is calculated as the ratio of dark (control) bacterial production $\left(\mathrm{BP} ; \mathrm{nM} \mathrm{C} \mathrm{h}^{-1}\right.$ ) to dissolved organic carbon concentration $\left(\mathrm{DOC}_{i} \mathrm{mM} \mathrm{C}\right)$

\& 4a). There are at least 2 possible mechanisms that could lead to the reduction in bioavailable DOM with exposure to solar radiation: (1) photomineralization removing bioavailable DOM and (2) photochemical transformations of photoreactive components leading to the condensation or polymerization of bioavailable DOM. Deciphering the relative importance of these mechanisms in the 2 study streams is beyond the scope of this study. The complex nature of stream DOM, 
however, may be an important factor contributing to the more common negative effect observed in this study of stream water DOM. Results from this study do suggest a couple of hypotheses that warrant further study to determine the role of photochemical processes in the cycling of DOM in streams.

The proportion of photoreactive, terrestrially derived DOM to algal-derived DOM may dictate the ultimate impact of solar radiation on DOM utilization (Tranvik \& Bertilsson 2001). This is relevant to DOM cycling in streams where proportions of algal and terrestrialderived sources of DOM vary substantially. Photochemical transformations of terrestrially derived DOM and subsequent polymerization and condensation of bioavailable forms of DOM (i.e. algal-derived DOM) can often reduce the bioavailability of DOM (Harvey et al. 1983, Kieber et al. 1997, Benner \& Biddanda 1998, Tranvik \& Kokalj 1998). During the 3 periods when solar radiation had a negative impact on bacterial production in Huey Hollow, the $\delta^{13} \mathrm{C}_{\mathrm{DOM}}$ suggested a larger input of algal derived DOM relative to spring (Fig. 3). Although algal inputs were not evident in the isotopic signatures of Moore Creek DOM, extensive growth of filamentous algae was observed in summer. The large pool of more refractory, soil-derived DOM present in Moore Creek likely masked the smaller and more bioavailable algal inputs (Ziegler \& Brisco 2004). The negative impact of solar radiation of DOM utilization could have been the result of condensation of algal inputs with more refractory soil-derived components dominating Moores Creek DOM.

Elevated levels of bioavailable DOM appears to lead to a reduction in available DOM with exposure to solar radiation (Geller 1986, Obernosterer et al. 1999, Tranvik \& Bertilsson 2001), while more refractory DOM is usually rendered more bioavailable with exposure (Miller \& Moran 1997). The results from both the Huey Hollow and Moores Creek incubations were consistent with this trend with the exception of the Moores Creek incubations in spring (Fig. 2). During that period the relative bioavailability of DOM was the lowest observed, and the exposure of DOM actually reduced its bioavailability further. The reason for this discrepency is beyond the scope of this study, however, one hypothesis for the further reduction in DOM bioavailability with exposure to solar radiation may be UV-induced humification. The elevated ammonium concentrations observed in Moores Creek in spring imply an excess supply of this nutrient which may have participated in photochemically enhanced humification. Exposure of DOM to solar radiation in seawater with excess ammonium, for example, can generate intermediates in the formation of humic substances (Kieber et al. 1997). Such a mechanism, if realized, could explain the reduction in the bioavailability of DOM in these waters.
Although only speculative at this point, this mechanism warrants further investigation considering the ramifications it may have on nutrient processing and transport in small streams impacted by nutrientenrichment.

Acknowledgements. Thanks are due to J. Baird, E. Findlay, J. Hamilton, T. Millican, and K. Mitchell for their help with fieldwork and lab analyses. We thank S. Billings and 3 anonymous reviewers for insightful criticism on earlier drafts. This research was supported by NSF grant DEB 0139439.

\section{LITERATURE CITED}

Amon RMW, Benner R (1996) Photochemical and microbial consumption of dissolved organic carbon and dissolved oxygen in the Amazon River system. Geochim Cosmochim Acta 60:1783-1792

Anesio AM, Tranvik LJ, Graneli W (1999) Production of inorganic carbon from aquatic macrophytes by solar radiation. Ecology 80:1852-1860

Benner R, Biddanda B (1998) Photochemical transformations of surface and deep marine dissolved organic matter: effects on bacterial growth. Limnol Oceanogr 43: 1373-1378

Benner R, Strom M (1993) A critical evaluation of the analytical blank associated with DOC measurements by hightemperature catalytic oxidation. Mar Chem 41:153-160

Bernhardt ES, Likens GE (2002) Dissolved organic carbon enrichment alters nitrogen dynamics in a forest stream. Ecology 83:1689-1700

Bertilsson S, Tranvik K (1998) Photochemically produced carboxylic acids as substrates for freshwater bacterioplankton. Limnol Oceanogr 43:885-895

Biddanda BA, Cotner JB (2003) Enhancement of dissolved organic matter bioavailability by sunlight and its role in the carbon cycle of Lakes Superior and Michigan. J Great Lakes Res 29:228-241.

Boavida MJ, Wetzel RG (1998) Inhibition of phosphatase activity by dissolved humic substances and hydrolytic reactivation by natural ultraviolet light. Freshw Biol 40: 285-293

Bratbak G (1985) Bacterial biovolume and biomass estimations. Appl Environ Microbiol 49:1488-1493

Bushaw KL, Zepp RG, Tarr MA, Schulz-Janser D \& 5 others (1996) Photochemical release of biologically available nitrogen from aquatic dissolved organic matter. Nature 381:404-407

Clair TA, Sayer BG (1997) Environmental variability in the reactivity of freshwater dissolved organic carbon to UV-B. Biogeochemistry 36:89-97

Engelhaupt E, Bianchi TS, Wetzel RG, Tarr MA (2002) Photochemical transformations and bacterial utilization of highmolecular-weight dissolved organic carbon in a southern Louisiana tidal stream (Bayou Trepagnier). Biogeochemistry 62:39-58

Espeland EM, Wetzel RG (2001)Complexation, stabilization, and UV photolysis of extracellular and surface-bound glucosidase and alkaline phosphatase: implications for biofilm microbiota. Microb Ecol 42:572-585

Francko DA, Heath, RT (1979) Functionally distinct classes of complex phosphorus compounds in lake water. Limnol Oceanogr 24:463-473

Gao H, Zepp RG (1998) Factors influencing photoreactions of 
dissolved organic matter in a coastal river of the Southeastern United States. Environ Sci Technol 32:2940-2946

Gardner WW, Wynne DS, Dunstan WM (1976) Simplified procedure for the manual analysis of nitrate in seawater. Mar Chem 4:393-396

Garner BA, Cox JB (1979) Soil survey of Crawford County, Arkansas. US Dep Agric Soil Conserv Serv, Washington DC

Geller A (1986) Comparison of mechanisms enhancing biodegradability of refractory lake water constituents. Limnol Oceanogr 31:755-764

Goldstone JV, Voelker BM (2000) Chemistry of superoxide radical in seawater: CDOM associated sing of superoxide in coastal waters. Environ Sci Technol 349:1043-1048

Goldstone JV, Pullin MJ, Bertilsson S, Voelker BM (2002) Reactions of hydroxyl radical with humic substances: Bleaching, mineralization, and production of bioavailable carbon substrates. Environ Sci Technol 36:364-372

Graneli W, Lindell M, Tranvik L (1996) Photooxidative production of dissolved inorganic cargon in lakes of different humic content. Limnol Oceanogr 41:698-706

Harper MD, Phillips WW, Haley GJ (1969) Soil survey of Washington County, Arkansas. US Dep Agric Soil Conserv Serv, Washington DC

Harvey GA, Boran DA, Chesal LA, Tokar JM (1983) The structure of marine fulvic and humic acids. Mar Chem 12:119-132

Johannssen SC, Miller WL (2001) Quantum yield for the photochemical production of dissolved inorganic carbon in seawater. Mar Chem 76:271-283

Kaplan LA, Newbold JD (1993) Biogeochemistry of dissolved organic carbon entering streams. In: Ford TE (ed) Aquatic microbiology: an ecological approach. Blackwell Scientific, Oxford, p 139-165

Kieber DJ, McDaniel J, Mopper K (1989) Photochemical source of biological substrates in seawater: implications for carbon cycling. Nature 341:637-639

Kieber DJ, Hydro LH, Seaton PJ (1997) Photooxidation of triglycerides and fatty acids in seawater: implication toward the formation of marine humic substances. Limnol Oceanogr 42:1454-1462

Kirchman D, K'nees E, Hudson R (1985) Leucine incorporation and its potential as a measure of protein synthesis by bacteria in natural aquatic systems. App Environ Microbiol 49:599-607

Koopmans DJ, Bronk DA (2002) Photochemical production of dissolved inorganic nitrogen and primary amines from dissolved organic nitrogen in waters of 2 estuaries and adjacent surficial groundwaters. Aquat Microb Ecol 26: 295-304

Lara RJ, Hubberten U, Thomas DN, Baumann MEM, Kattner G (1997) Dissolved organic matter studies in enclosed systems: Application of hydrophobic fractionation for the assessment of organic nitrogen dynamics. J Mar Syst, 13: $155-161$

Lindell MJ, Graneli HW, Bertilsson S (2000) Seasonal photoreactivity of dissolved organic matter from lakes with contrasting humic content. Can J Fish Aquat Sci 57: $875-885$

Miller WL, Zepp RG (1995) Photochemical production of dissolved inorganic carbon from terrestrial organic matter: Significance to the oceanic organic carbon cycle. Geophys Res Lett 22:417-420

Miller WL, Moran MA (1997) Interaction of photochemical and microbial processes in the degradation of refractory dissolved organic matter from a coastal marine environment. Limnol Oceanogr 42:1317-1324
Moran MA, Hodson RE (1989) Formation and bacterial utilization of dissolved organic carbon derived from detrital lignocellulose. Limnol Oceanogr 34:1034-1047

Moran MA, Zepp RG (1997) Role of photoreactions in the formation of biologically labile compounds from dissolved organic matter. Limnol Oceanogr 42:1307-1316

Moran MA, Sheldon, WM Jr, Zepp RG (2000) Carbon loss and optical property changes during long-term photochemical and biological degradation of estuarine dissolved organic matter. Limnol Oceanogr 45:1254-1264

Nagata T, Fukuda R, Koike I, Kogure K, Kirchman DL (1998) Degradation by bacteria of membrane and soluble protein in seawater. Aquat Microb Ecol 14: 29-37

Obernosterer I, Benner R (2004) Competition between biological and photochemical processes in the mineralization of dissolved organic carbon. Limnol Oceanogr 49:117-124

Obernosterer I, Reitner B, Herndl GJ (1999) Contrasting effects of solar radiation on dissolved organic matter and its bioavailability to marine bacterioplankton. Limnol Oceanogr 44:1645-1654

Opsahl SP, Zepp RG (2001) Photochemically-induced alteration of stable carbon isotope ratios $\left(\delta^{13} \mathrm{C}\right)$ in terrigenous dissolved organic carbon. Geophys Res Lett 28: 2417-2420

Osburn CL, Morris DP, Thorn KA, Moeller RE (2001) Chemical and optical changes in freshwater dissolved organic matter exposed to solar radiation. Biogeochemistry 54: 251-278

Peterson BJ, Wollheim WM, Mulholland PJ, Webster JR and 10 others (2001) Control of nitrogen export from watersheds by headwater streams. Science 292:86-90

Porter KG, Feig YS (1980) The use of DAPI for identifying and counting aquatic microflora. Limnol Oceanogr 25: 943-948

Reitner B, Herndl GJ, Herzig A (1997) Role of ultraviolet-B radiation on photochemical and microbial oxygen consumption in a humic-rich shallow lake. Limnol Oceanogr 42:950-960

Saunders GW, Cummins KW, Gak DZ, Pieczynska E, Straskrabova V, Wetzel RG (1980) Organic matter and decomposers. In Le Cren ED, Lowe-McConnell RH (eds) The functioning of freshwater ecosystems. Cambridge University Press, Cambridge, p 341-392

Solorzano L (1969) The determination of ammonium in natural waters by phenolhypochlorite method. Limnol Oceanogr 14:799-801

Sondergaard M, Middleboe M (1995) A cross-system analysis of labile dissolved organic carbon. Mar Ecol Prog Ser 118: 283-294

Strickland JDH, Parsons TR (1972) A practical handbook of seawater analysis. Bull Fish Res Board Can 167

Tranvik LJ (1998) Decreased bioavailability of algal DOC due to interactive effects of UV radiation and humic matter. Aquat Microb Ecol 14:301-307

Tranvik LJ, Bertilsson S (2001) Contrasting effects of solar UV radiation on dissolved organic sources for bacterial growth. Ecol Lett 4:458-463

Tranvik LJ, Kokalj S (1998) Decreased biodegradability of algal DEOC due to interactive effects of UV radiation and humic matter. Aquat Microb Ecol 14:301-307

Turley CM (1993) Direct estimates of bacterial numbers in seawater samples without incurring cell loss due to sample storage. In: Kemp P, Sherr B, Sherr E, Cole JJ (eds) Handbook of methods in aquatic microbial ecology. Lewis Publishers, Boston, MA, p 143-147

Vaughan PP, Blought NV (1998) Photochemical formation of hydroxyl radical by constituents of natural water. Environ 
Sci Technol 32:2947-2953

Vendrell PF, Nelson MA, Cash LW, Steele KF, McNew RW, Murdock JF, Edwards DR (1997) Continuation of Illinois River water quality monitoring of Moores Creek 94-222. Arkansas Water Resources Center and Arkansas Soil and Water Conservation Commission. Fayuetteville, AR

Volk CJ, Volk CB, Kaplan LA (1997) Chemical composition of biodegradable dissolved organic matter in streamwater.

Editorial responsibility: Gerhard Herndl,

Den Burg, The Netherlands
Limnol Oceanogr 42:39-44

Ziegler SE, Benner R (2000) Effects of solar radiation on dissolved organic matter cycling in a subtropical seagrass meadow. Limnol Oceanogr 45: 257-266

Ziegler SE, Brisco SL (2004) Relationships between the isotopic composition of dissolved organic carbon and its bioavailability in contrasting Ozark streams. Hydrobiologia 513:153-169

Submitted: March 26, 2004; Accepted: July 19, 2004 Proofs received from author(s): October 25, 2004 